\title{
Validity of ultrasound in detecting benign and malignant ovarian cysts
}

\author{
Tavga Omar Jaffara ${ }^{a}$ Saeed Nadhim Younis ${ }^{b}$ \\ ${ }^{a}$ Radiologist, Soran General Hospital, Erbil, ${ }^{b}$ Assistant Professor in Diagnostic Radiology, Department of Surgery, Hawler \\ Medical University, Erbil. \\ Correspondence: Saeed Nadhim Younis. Department of Surgery, Hawler Medical University, Erbil, Iraq. \\ Email:drsaeedagha@yahoo.com.
}

Received: $8^{\text {th }}$ Jan. 2013; Accepted: $19^{\text {th }}$ May 2013.

\begin{abstract}
Background: Ovarian tumors are the second most common gynecological malignancy and the fourth most common cancer death in women, which is characterized by few or late symptoms, often called the silent killer. Early detection of ovarian carcinoma could be a formidable challenge and an elusive task.

Objectives: To Study sonographic features of benign and malignant ovarian cysts, to find the incidence of benign and malignant ovarian tumours and to determine the accuracy of ultrasound in differentiating benign from malignant ovarian cysts comparing with histopathology results.

Patients and methods: This was a cross sectional study. Convenient sample taken from a population consists of 65 women in reproductive age, scheduled for surgery because of ovarian cysts. They underwent preoperative ultrasound examination, done in the Radiology Department of Maternity and Rizgari Teaching Hospitals, Erbil city, North of Iraq. The mean patient age was 30.25 years ranging from 14-46 years.

Results: Out of 65 cases, 60 (92.3\%) were benign, and 5 cases $(7.7 \%)$ were malignant. Using sonographic morphological scoring, scores equal or more than 3 was regarded as malignant (the scoring system included wall thickness, shadowing, septa and echogenicity). The accuracy, sensitivity and specificity of ultrasound were $91 \%, 100 \%$ and $90 \%$ respectively.

Conclusion: Gray scale and Doppler ultrasound yield high diagnostic accuracy in discrimination between benign and malignant cysts. Benign cysts are more common than malignant cysts in female at reproductive age. Mature cystic teratoma (dermoid) is the commonest type of ovarian tumors. Cysts more than $10 \mathrm{~cm}$ in maximum diameter, multilocular cysts are more likely to be malignant. The presence of ascites also favors malignancy.
\end{abstract}

Keywords: Ovarian cyst, Doppler ultrasound, pelvic mass.

\section{فائدة الفحص بالأمواج الصوتية في تشخيص أورام المبيض الحميدة والخبيثة والتفريث بينهما}

الخلفية: تعد أور ام المبيض ثاني أكثر الأورام النسائية شيو عا وواحدة من الأسباب المهمة المؤدية للوفاة بسبب الأمر اض السرطانية

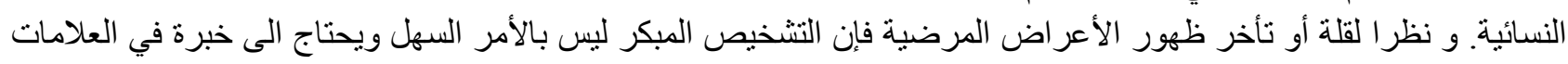

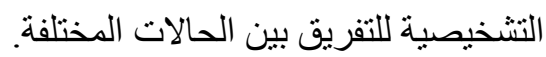

الأهداف: للتفريق بين أكياس المبيض الحميدة والخبيثة بواسطة الفحص بالأمواج فوق الصوتية ومعرفة مدى دقة الأمو اج فوق الصوتية في هذا المجال.

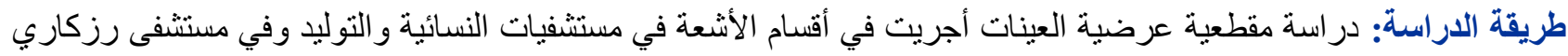

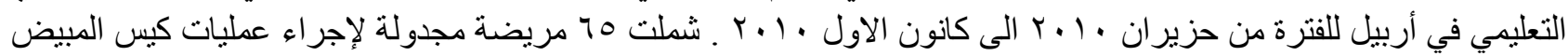

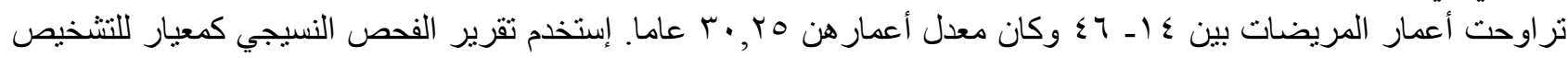
النهائي.

النتائج و الخلاصة: أثبت الفحص بالأمواج فوق الصوتية بضمنها الدوبلر دقة عالية في التفريق بين أكياس المبيض الحميدة

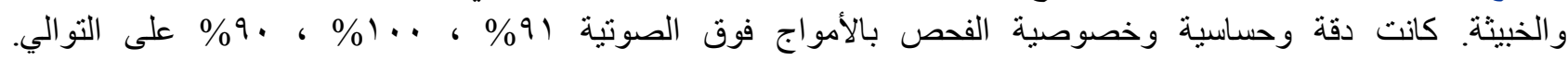


A $\mathrm{n}$ ovarian cyst is a sac filled with liquid or semi-liquid material arising in an ovary which is most common cause of pelvic masses in women, frequently asymptomatic and often resolves spontaneously or present as ovarian cyst accidents include cyst rupture, hemorrhage and torsion, however, ovarian cysts can herald an underlying malignant process. They can develop from the neonatal period to post menopause ${ }^{(1)}$. Incidence of ovarian cysts in the general population is difficult to be estimated. Certain cysts are functional and generally not operated, estimated that $7 \%$ of premenopausal women have ovarian cyst and it is important to realize that the majority of adnexial masses particularly in premenopausal women are benign ${ }^{(2)}$. Different scoring systems based on morphological and Doppler indices can be used to differentiate benign from malignant ovarian cysts. Large cyst size more than $10 \mathrm{~cm}$, thick more than $3 \mathrm{~mm}$, nodular septations, central rather than peripheral vascularity and papillary formation are ultrasonic morphological features that favor malignancy. Resistant index less than 0.6 and pulsatile index less than one considered as malignant, while resistant index of more than 0.6 and pulsatile index of greater than one regard as benign ${ }^{(3)}$.

The aim of this study was to evaluate the diagnostic accuracy of preoperative ultrasound in differentiating benign from malignant ovarian cysts, to study the ultrasonic features of benign and malignant cysts and to study the incidence of different ovarian cysts particularly in our locality because data about this incidence is limited.

\section{PATIENTS AND METHODS}

Study design: This was cross sectional study. Convenient sample taken from a population consists of 65 women in reproductive age scheduled for surgery because of ovarian cysts. They were recruited for the study and underwent preoperative ultrasound examination done in Radiology Department of Maternity and Rizgari Teaching Hospitals, Erbil, North of Iraq. The mean patient age was 30.25 years ranging from 14-46 years.

Period of the study: From June 2010 to December 2010.

Methods: Patients underwent ultrasound examination preoperatively regardless to menstruation days. The machines used were ultrasound machine Fukuda (denshi uf 850 xtd) for gray scale and color Doppler transabdominal examination and Siemens Adara sonoline for transvaginal ultrasound examination.

Technique of examination: For transabdominal examination, the patient was examined with bladder adequately distended. A 3.5 $\mathrm{MHz}$ probe frequency was used with the patient in supine position. For transvaginal sonography, an empty bladder was preferred using $7 \mathrm{MHz}$ transducer, and patients were examined in supine position, with knees gently flexed and hips slightly elevated. The transducer was prepared with ultrasound gel, fitted with a condom, then a small amount of lubricant gel applied to allow easy insertion of the probe, then the probe was advanced approximately seven to ten $\mathrm{cm}$ into vagina directing the sound beam by rotation and angling the probe from anterior to posterior and sliding in and out.

The following morphologic characteristic of the cyst were studied:

- $\quad$ Size (maximum diameter of cyst).

- Septum: it is a strand of tissue running across the cyst cavity from one internal surface to contra lateral side.

- Locularity: unilocular cyst is without septa, multilocular with at least one septum.

- Echogenisity: recorded as (sonolucent or lowlevel echo or echogenic core) or mixed echogenisity.

- Shadowing: presence of acoustics shadowing

- Solid component: when the cyst contains echogenic material and reported absent or not.

- Ascites defined by any fluid in pouch of Douglas was measured in a sagittal plane and recorded as present or absence.

- Wall thickness: inner wall of the cyst: either smooth or irregular if there is any papillary projection regarded as irregular. Papillary projection defined as any solid projection from the cyst cavity with height equal to or greater than three $\mathrm{mm}^{(4)}$.

Cysts less than five $\mathrm{cm}$ in married women examined by vaginal ultrasound for better characterization of morphology.

Data from wall structure, shadowing, septa, and echogenecity entered into scoring system seen in Table 1. Scores equal or more than three regarded as malignant and score less than three regarded as benign ${ }^{(5)}$. 
Table 1. Morphologic Scoring. Lerner et al ${ }^{(5)}$

\begin{tabular}{|l|c|c|c|c|}
\hline \multicolumn{1}{|c|}{ Morphology } & $\mathbf{0}$ & $\mathbf{1}$ & $\mathbf{2}$ & $\mathbf{3}$ \\
\hline Wall Structure & $\begin{array}{c}\text { Smooth or small irregularities }<3 \\
\mathrm{~mm}\end{array}$ & - & $\begin{array}{c}\text { Solid or not } \\
\text { applicable }\end{array}$ & $\begin{array}{c}\text { Papillarities } \geq 3 \\
\mathrm{~mm}\end{array}$ \\
\hline Shadowing & Yes & No & - & - \\
\hline Septa & None or thin $(<3 \mathrm{~mm})$ & Thick $(\geq 3 \mathrm{~mm})$ & - & - \\
\hline Echogenicity & $\begin{array}{c}\text { Sonolucent or low-level echo or } \\
\text { echogenic core. }\end{array}$ & - & - & Mixed or high \\
\hline
\end{tabular}

After visualization of cyst by B mode sonography color Doppler sonography and pulsed wave Doppler were used for detection of blood flow, visualization of the waveform and blood flow indices of the ovarian artery (the pulsatility index and the resistance index). Resistant index less than 0.6 and pulsatile index less than one regarded as malignant; resistant index of more than 0.6 and pulsatile index of greater than one regarded as benign ${ }^{(3)}$. The results of the ultrasound examination were compared with those of histological examination of the resected specimens.

Statistical analysis: Statistical package for social sciences SPSS version 18 was used for data entry and analysis. Parametric tests (Chi square) and $t$ test were used for normally distributed data. $P$ value less than 0.05 was considered significant. Each entry was double checked to avoid any possible mistakes. Graphs and tables were drawn to summarize and present the results.

Ethical consideration: After ethical approval was obtained for this study by scientific committees of Hawler Medical College and Maternity and Rizgari Teaching Hospitals, the verbal consent was taken from all the enrolled patients, all of them informed about the purpose and the procedure of the study.

\section{RESULTS}

Out of 65 cysts 60 (92.3\%) were benign and 5 $(7.7 \%)$ were malignant. Dermoid cyst was the commonest benign cyst, forming $25 \%$, serous cystadenocarcinoma was the commonest malignant and mucinous adenocarcinoma was the least common malignant cyst, Figure 1 shows the frequency of tumour types according to the histopathological results.

Sixty percent of malignant cysts showed maximum diameter of more than $10 \mathrm{~cm}$, while only $23.3 \%$ of benign cysts showed maximum diameter more than $10 \mathrm{~cm}$ (Table 2)
Eighty percent of malignant cysts showed multilocularity, while only $30 \%$ of benign cysts showed multilocularity (Table 3 ).

Ascites was positive in $60 \%$ of malignant cysts while it was positive in only $8.3 \%$ of benign cases (Table 4). Ascites in benign ovarian masses was seen in fibromas and in large tumors irritating the endometrium and also in endometriotic cysts.

Relationship of Doppler indices with malignancy: there was significant statistical association between malignant status (malignant and benign) with resistive index ( $t=10.90, p$-value, $<0.001)$ and pulsatile index $(t=24.350, p$-value $<0.001)$ shown in Table 5.

The sensitivity, specificity and accuracy of ultrasound in differentiating benign from malignant cysts were $100 \%, 90 \%$ and $91 \%$ respectively and this is shown in Table 6.

Figures 2 (A-F) shows the different sonographic features of benign and malignant ovarian cysts: $\mathbf{A}$ : hyperechoic fat fluid level, diagnosis was mature cystic teratoma. B: plug with posterior acoustic shadowing inside smooth wall cyst, diagnosis was dermoid cyst. C: thin septation less than $3 \mathrm{~mm}$, diagnosis was mucinous serous cystadenoma. D: thick more than $3 \mathrm{~mm}$ irregular septation. $\mathbf{E}$ : thin wall cysts, no papillary projection diagnosis were corpus luteal cyst. F: cystic mass with internal echoes and multiple papillaries diagnosis was serous cystadenocarcinoma.

Table 2. Relationship between malignancy and tumor size.

\begin{tabular}{|c|c|c|c|c|c|}
\hline & \multicolumn{3}{|c|}{ Size } & \multirow{2}{*}{ Total } & \multirow{2}{*}{$\begin{array}{c}P \\
\text { value }\end{array}$} \\
\hline & $<5 \mathrm{~cm}$ & $\begin{array}{l}5-10 \\
\mathrm{~cm}\end{array}$ & $>10 \mathrm{~cm}$ & & \\
\hline Benign & $\begin{array}{c}8 \\
(13.3 \%)\end{array}$ & $\begin{array}{c}38 \\
(63.3 \%)\end{array}$ & $\begin{array}{c}14 \\
(23.3 \%)\end{array}$ & $\begin{array}{c}60 \\
(100 \%)\end{array}$ & 0.1 \\
\hline Malignant & 0 & $2(40 \%)$ & $3(60 \%)$ & $\begin{array}{c}5 \\
(100 \%)\end{array}$ & 0.1 \\
\hline Total & $\begin{array}{c}8 \\
(12.3 \%)\end{array}$ & $\begin{array}{c}40 \\
(61.5 \%)\end{array}$ & $\begin{array}{c}17 \\
(26.2 \%)\end{array}$ & $\begin{array}{c}65 \\
(100 \%)\end{array}$ & 0.1 \\
\hline
\end{tabular}


Table 3. Relationship between malignancy and locularity.

\begin{tabular}{|c|c|c|c|c|}
\hline \multirow{2}{*}{ Locularity } & \multicolumn{2}{|c|}{ Malignany } & \multirow{2}{*}{ Total } & $\begin{array}{c}\text { P } \\
\text { value }\end{array}$ \\
\cline { 2 - 4 } Benign & Malignant & $\begin{array}{c}22 \\
(33.8 \%)\end{array}$ & 0.02 \\
\hline Multilocular & $18(30 \%)$ & $4(80 \%)$ & $\begin{array}{c}43 \\
(66.2 \%)\end{array}$ & 0.02 \\
\hline Total & $60(100 \%)$ & $5(100 \%)$ & $\begin{array}{c}65 \\
(100 \%)\end{array}$ & 0.02 \\
\hline
\end{tabular}

$\mathrm{P}$ value $=0.02$ statistically significant.

Table 5. Relationship between malignancy and Doppler indices.

\begin{tabular}{|c|c|c|c|c|c|c|c|}
\hline \multirow{3}{*}{ Index } & \multicolumn{7}{|c|}{ t-test } \\
\hline & \multirow{2}{*}{$\mathbf{T}$} & \multirow{2}{*}{ Df } & \multirow{2}{*}{$P$ value } & \multirow{2}{*}{$\begin{array}{c}\text { Mean } \\
\text { difference }\end{array}$} & \multirow{2}{*}{$\begin{array}{l}\text { Std.error } \\
\text { difference }\end{array}$} & \multicolumn{2}{|c|}{$\begin{array}{l}95 \% \text { confidence interval } \\
\text { of the difference }\end{array}$} \\
\hline & & & & & & Lower & upper \\
\hline $\mathrm{R} 1$ & 4.263 & 15.722 & $0.001^{\circ}$ & 0.479 & 0.116 & 0.249 & 0.744 \\
\hline $\mathrm{P} 1$ & 3.228 & 20.138 & $0.004^{*}$ & 0.409 & 0.127 & 0.145 & 0.674 \\
\hline
\end{tabular}

* Statistically significant, $\mathrm{Df}=$ degree of freedom, std= standard error.

Table 6. Sensitivity, specificity and accuracy of ultrasound.

\begin{tabular}{|c|c|c|c|}
\hline \multirow{2}{*}{$\begin{array}{c}\text { Total ultrasound } \\
\text { score }\end{array}$} & \multicolumn{2}{|c|}{ Histopathology } & \multirow{2}{*}{ Total } \\
\cline { 2 - 3 } & Malignant & Benign & \\
\hline Malignant & 5 & 6 & 11 \\
\hline Benign & 0 & 54 & 54 \\
\hline Total & 5 & 60 & 65 \\
\hline
\end{tabular}

Sensitivity $=100 \%$, specificity $=90 \%$, accuracy $=91 \%$.

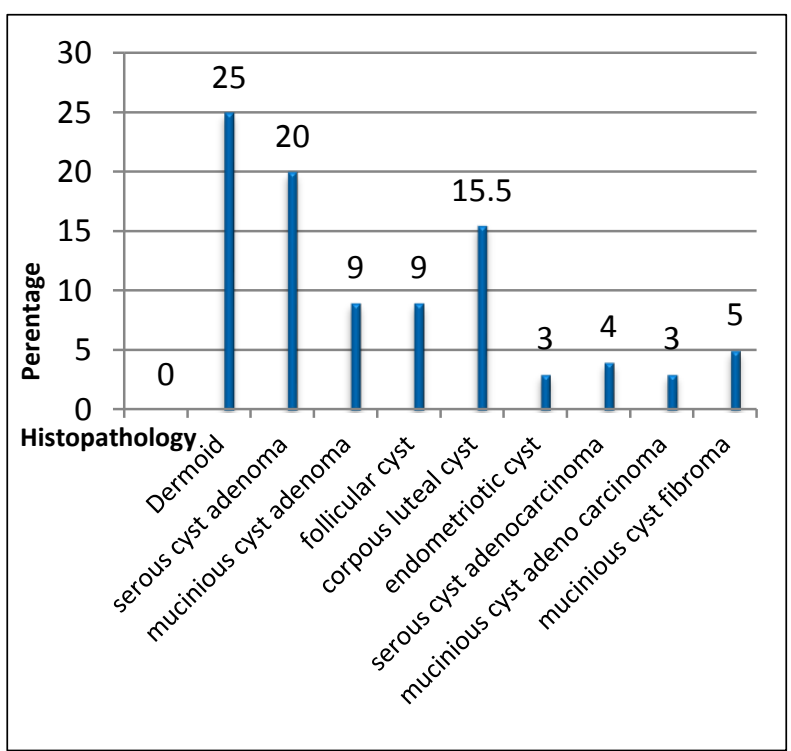

Figure 1. Frequency of types of tumour according to histopathology.
Table 4. Relationship between ascites and malignancy.

\begin{tabular}{|c|c|c|c|c|}
\hline \multirow{2}{*}{ Ascites } & \multicolumn{2}{|c|}{ Ovarian cysts } & \multirow{2}{*}{ Total } & \multirow{2}{*}{ P value } \\
\cline { 2 - 3 } & Benign & Malignant & & 0.001 \\
\hline Positive & $\begin{array}{c}5 \\
(8.3 \%)\end{array}$ & $3(60 \%)$ & $8(12.3 \%)$ & 0.001 \\
\hline Negative & $\begin{array}{c}55 \\
(91.7 \%)\end{array}$ & $2(40.0 \%)$ & $57(87.7 \%)$ & 0.001 \\
\hline Total & $\begin{array}{c}60 \\
(100 \%)\end{array}$ & $5(100 \%)$ & $65(100 \%)$ & 0.00 \\
\hline
\end{tabular}

$P$ value $=0.001$ statistically significant

.




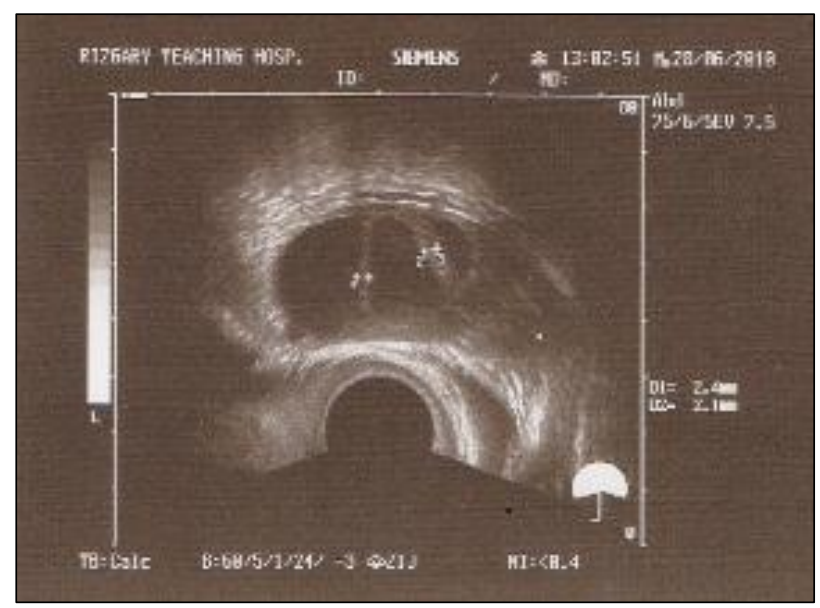

Figure 2.C.

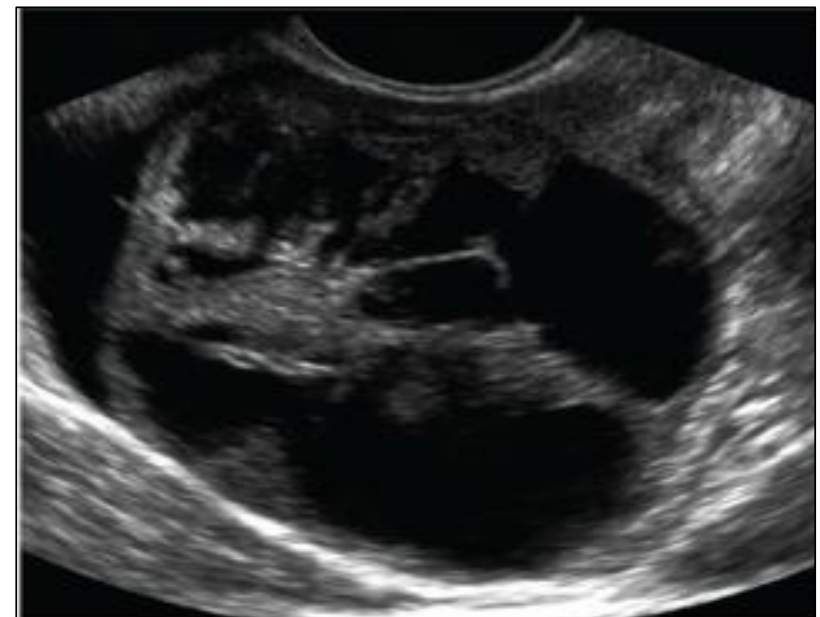

Figure 2.D.

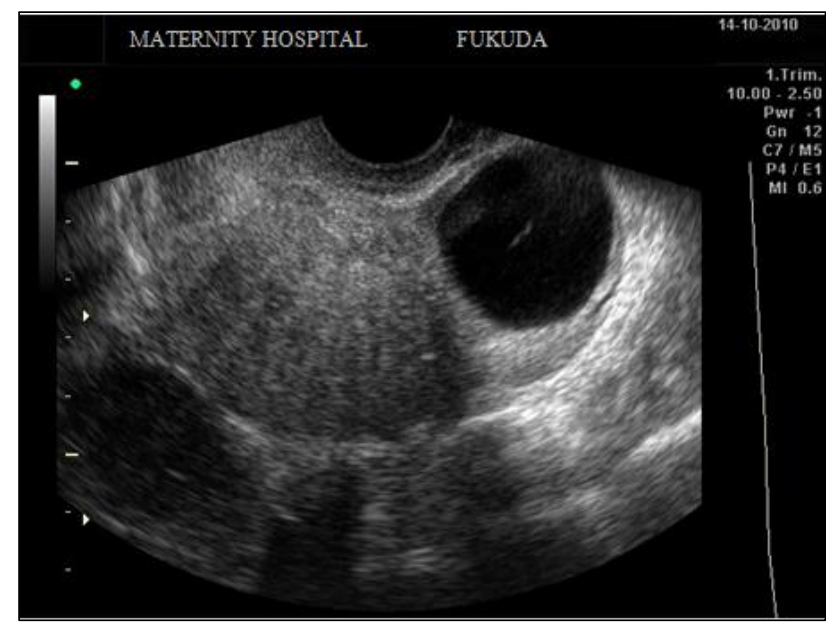

Figure 2.E.

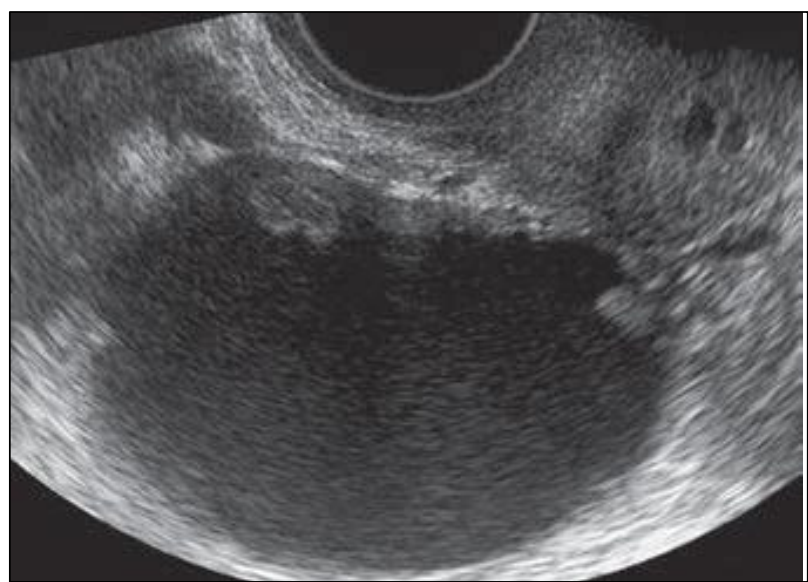

Figure 2.F.

Figure 2. Sonographic features of different ovarian cysts.

\section{DISCUSSION}

The exact nature of the ovarian tumor cannot be confirmed preoperatively just by clinical examination. Ultrasonography has been recommended by the National Institute of Health as a preferred means of diagnosis ${ }^{(2)}$. Ultrasonography continues to be the primary imaging modality used to identify and characterize adnexal masses. The current study shows most of the cases were benign $60(92.3 \%)$ and few were malignant 5 (7.7\%); this goes with study done by Yasmin et al, in which $89.7 \%$ of cysts were benign and $10.29 \%$ malignant ${ }^{(6)}$. Dermoid cyst was the commonest among benign cases (24.6\%) and this is in accord with study done by Maged MK ${ }^{(7)}$, also coincident with study done by Paursa etal ${ }^{(8)}$. Serous cyst adenocarcinoma is the commonest malignant type which goes with a study done by Clarke et al ${ }^{(9)}$. In this study $60 \%$ of malignant cases have size more than $10 \mathrm{~cm}$ this agree with the study done by Shah et al, in which $57 \%$ of malignant tumors were more than $10 \mathrm{~cm}{ }^{(10)}$. In current study benign tumors were unilateral in 95\% and bilateral in $5 \%$, all bilateral cases were dermoid cysts, this constitutes $18.75 \%$ of total dermoid cysts, and this is similar to a study done by Hagen-Ansert who found that up to $15 \%$ of dermoid cysts are bilateral ${ }^{(11)}$. Our study shows that there was significant association between multilocularity and malignancy, $80 \%$ of malignant tumors were multilocular, and this is coincident with that stated by Kurjak et al: ultrasonic sign of malignant ovarian tumors include multilocular cyst ${ }^{(12)}$. Ascites found in $60 \%$ of malignant tumors so 
there was significant association between ascites and malignancy, this coincident with that stated by Brown et al: ascites is an indirect indicator of malignancy ${ }^{(13)}$, and also a significant association between malignancy and resistive index $(t=10.90$, $\mathrm{p}$-value, $<0.001)$ and pulsatile index $(\mathrm{t}=24.350$, $\mathrm{p}$ value $<0.001)$ noticed. This is coincident with that stated by Crofton et al: RI less than 0.6 and PI less than one are suggestive of malignancy ${ }^{(3)}$ and that stated by Kurjak et al: $\mathrm{PI}<1$ is suggestive of malignant disease ${ }^{(12)}$. The current study showed the sensitivity, specificity and accuracy of gray scale ultrasound $100 \%, 90 \%$ and $91 \%$ respectively and this is comparable to studies done by Lerner et al $^{(5)}$ and Valentin et al ${ }^{(14)}$.

\section{CONCLUSION}

Ultrasound showed high diagnostic accuracy of $91 \%$ in differentiating between benign and malignant ovarian cysts. Large cysts more than $10 \mathrm{~cm}$ in maximum diameter, multilocular cysts and ascites are features favoring malignancy. Benign cysts are more common than malignant cysts $92.3 \%$ versus $7.7 \%$.

\section{REFERENCES}

1. Helm CW. Ovarian Cysts. eMedicine [online].[cited 2010 Feb 2]. Available from: URL: http://emedicine. medscape.com/article/255865-overview.

2. Bottomley C, Bourne T. Diagnosis and management of ovarian cyst accidents. Best Pract Res Clin Obstet Gynaecol. 2009; 23 (5):711-724.

3. Crofton M. Gynecological Imaging. In: Sutton D, editor. Textbook of radiology and imaging. $7^{\text {th }}$ edition. Philadelphia: Churchill Livingstone; 2002. p.1069-1104.
4. Timmerman D, Valentin L, Bourne TH, Collins WP, Verrelst $\mathrm{H}$, Vergote I. Terms, definitions and measurements to describe the sonographic features of adnexal tumors: a consensus opinion from the International Ovarian Tumor Analysis (IOTA) group. Ultrasound Obstet Gynecol.2000;16:500-505.

5. Lerner JP, Timor-Tritsch IE, Federman A, et al. Transvaginal ultrasonographic characterization of ovarian masses with an improved, weighted scoring system. Am J Obstet Gynecol.1994; 170 (1):81-85.

6. Yasmin S, Yasmin A, Asif M. Clinicohistological Pattern of Ovarian Tumours in Peshawar Region. J Ayub Med Coll Abbottabad.2008; 20(4):11-13.

7. Magid MK. Transabdominal ultrasound evaluation of ovarian cysts in reproductive age group .High diploma thesis. University of Salahadin- Erbil, Collage of Medicine. Iraq. 2003.

8. Pourissa M, Refahi S, Moghangard F. The Diagnostic Accuracy of Abdominal Ultrasound Imaging for Detection of Ovarian Masses. Iran. J. Radiol.2007; 4(2):103-107.

9. Clarke SE, Grimshaw R, Rittenberg P, Kieser K, Bentley J. Risk of Malignancy Index in the Evaluation of Patients With Adnexal Masses. J Obstet Gynaecol Can.2009; 31 (5):440-445.

10. Shah SH, Hishikar VA. Incidence and Management of Ovarian Tumours. Bombay Hospital Journal 2008; 50(1):30-33.

11. Hagen-Ansert SL, Vander Werff BJ. Pathology of the ovaries. In: Hogen-Ansert SL.Textbook of Diagnostic Ultrasonohraphy. USA: Mosby Elsevier; 2006.p.919-945. 12. Kurjak A, Chervenak FA. Donald textbook of ultrasound in obstetrics and gynecology. $2^{\text {nd }}$ edition. New Delhi: Jaypee brothers medical publishers; 2008.

13. Brown DL, Dudiak KM, Laing FC. Adnexial Masses: US Characterization and Reporting. Radiology 2010; 254(2):342-354.

14. Valentin L. Pattern recognition of pelvic masses by gray-scale ultrasound imaging: the contribution of Doppler ultrasound. Ultrasound in Obstetrics and Gynecology 1999;15: 338-347. 